\title{
ANALISIS RISIKO PASCA PANEN TANDAN BUAH SEGAR (TBS) KELAPA SAWIT DI KABUPATEN DHARMASRAYA
}

\author{
Yulistriani $^{1}$, Cindy Paloma ${ }^{1}$, Hasnah $^{1}$
}

Email Author: yulistrianidarlis87@gmail.com

\begin{abstract}
One of the risks often faced by palm oil agribusiness is the post harvest risk of losing fresh fruit bunches (FFB) from each post-harvest chain (loss post-harvest). Palm oil which is a mainstay of plantation crops Dharmasraya region, its production from year to year is always the largest compared with other commodities. However, in 2015 palm oil production was decrease compared to the previous year. This study aims to analyze farmers' management capability in palm oil management, analyze the large loss of FFB yields in each chain from farmer (harvest) to final processing plant, analyze the probability and impact of post-harvest loss FFB and post-harvest post-harvest status in each post-harvest chain (stage). The large percentage of production losses to the total production of FFB produced is $3.85 \%$ for the land, $0.05 \%$ for the process of crude FFB checking (TPH), and 5.5\% in the factory sorting (PKS). The impact of losses resulting from post-harvest loss of FFB in total per hectare of land is $\mathrm{Rp} 2,848,528,41$ at factory sorting, and is the biggest loss compared to other chains.
\end{abstract}

Keywords: palm oil, post harvest risk, FFB

\section{LATAR BELAKANG}

Pembangunan subsektor kelapa sawit merupakan penyedia lapangan kerja yang cukup besar dan sebagai sumber pendapatan petani. Kelapa sawit merupakan salah satu komoditas yang memiliki andil besar dalam menghasilkan pendapatan asli daerah, produk domestik bruto, dan kesejahteraan masyarakat (Afifuddin, 2007).

Perkebunan kelapa sawit Indonesia meningkat dari sekitar 300 ribu Ha pada tahun 1980 menjadi sekitar 11,6 juta Ha pada tahun 2016. Perkebunan kelapa sawit di Indonesia berdasarkan data dari Direktorat Jenderal Perkebunan dikelompokan menjadi 3 jenis, yaitu Perkebunan Rakyat (PR)/smallholder, Perkebunan Besar Negara (PBN)/ Government,
Perkebunan Besar Swasta (PBS)/ Private.

Pengusahaan kelapa sawit di Sumatera Barat sedikit berbeda dengan gambaran secara nasional. Secara nasional, pengusahaan kelapa sawit didominasi oleh perkebunan swasta, sementara di Sumatera Barat sebagian besar lahan sawit berupa perkebunan rakyat. Sebesar 51\% dari total luas lahan sawit di Sumatera Barat merupakan perkebunan rakyat, sementara $46 \%$ adalah milik perkebunan swasta dan perkebunan milik pemerintah hanya berkontribusi sebesar 3\% (Dirjen Perkebunan, 2014). Karena industri kelapa sawit ini didominasi oleh petani kecil, setiap program pengembangan kelapa sawit tentunya manfaatnya terutama dapat dinikmati oleh petani kecil. 
Di perkebunan sawit rakyat, permasalahan umum yang sering dihadapi antara lain rendahnya produktivitas dan mutu produksinya. Sedangkan produksi CPO meningkat dari sekitar 700 ribu ton pada tahun 1980 menjadi 335 juta ton pada tahun 2016. Produktivitas tanaman kelapa sawit dipengaruhi oleh beberapa faktor, yaitu faktor lingkungan, faktor genetik, dan teknik budidaya tanaman. Faktor lingkungan (enforce) yang mempengaruhi produktivitas kelapa sawit meliputi faktor abiotik (curah hujan, hari hujan, tanah, topografi) dan faktor biotik (gulma, hama, jumlah populasi tanaman/ha). Faktor genetik (innate) meliputi varietas bibit yang digunakan dan umur tanaman kelapa sawit. Faktor teknik budidaya (induce) meliputi pemupukan, konservasi tanah dan air, pengendalian gulma, hama, dan penyakit tanaman, serta kegiatan pemeliharaan lainnya. Faktor-faktor tersebut saling berhubungan dan mempengaruhi satu sama lain (Pahan 2010).

Salah satu risiko yang sering dihadapi agribisnis kelapa sawit adalah risiko pasca panen yaitu kehilangan hasil tandan buah segar (TBS) dari setiap rantaipasca panen yang dilaluinya (loss post-harvest). $\quad \mathrm{Di}$ bagian awal pemanenan, aktivitas pemanenan yang tidak sesuai dengan standar mengakibatkan kurang optimalnya hasil TBS yang diperoleh seperti brondolan yang terlepas maupun TBS mentah yang terpanen. Ketika di pabrik, TBS kelapa sawit yang dihasilkan oleh petani akan diseleksi sesuai dengan standar pabrik sehingga menimbulkan losses berupa pengurangan hasil produksi akibat TBS tidak sesuai dengan kriteria pabrik.

$\begin{array}{ccc}\text { Berdasarkan } & \text { uraian } & \text { yang } \\ \text { disampaikan diatas, } & \text { maka } & \text { dapat }\end{array}$ disimpulkan rumusan masalah dari penelitian ini adalah:

1. Analisa kemampuan manajemen petani dalam pengelolaan perkebunan kelapa sawit rakyat di Kab. Dharmasraya ?

2. Berapa besar kehilangan hasil TBS kelapa sawit di setiap rantai pasca panen yang dilalui mulai dari lahan sampai ke tempat pengolahan akhir (pabrik) ?

3. Berapa kemungkinan kejadian, dampak dan status loss postharvest TBS kelapa sawit di setiap rantai yang dilalui ?

\section{METODE PENELITIAN}

Metode penelitian ini adalah deskriptif kualitatif melalui survey dan wawacara langsung terhadap petani kelapa sawit di Kabupaten Dharmasraya. Populasi dari penelitian ini adalah petani kelapa sawit di Kabupaten Dharmasraya yang mengelola kebunnya dengan pola kebun rakyat. Pengambilan sampel dilakukan dengan metode acak sederhana (simple random sampling) sebanyak 30 sampel. Sampel diambil secara purposive (sengaja) yaitu petani dengan luas lahan $\geq 2$ Ha dan tanaman telah menghasilkan.

Wawancara terstruktur dilakukan mulai dari aspek mengadaan saprodi (sarana produksi pertanian) sebagai subsistem hulu dalam agribisnis hingga ke subsistem hilir (panen, pemasaran dan penunjang). Selanjutnya dilakukan analisis masing-masing berdasrkan tujuan peneltian sebagai berikut:

1. Untuk tujuan pertama, hasil wawancara responden di lapangan di tabulasi kemudian dideskripsikan secara detil berdasarkan subsistem agribisnis hulu hingga hilir. 
2. Untuk tujuan kedua pengukuran kemungkinan terjadi resiko di analisis dengan beberapa tahapan sebagai berikut.

\section{Menghitung rata-rata kejadian berisiko (kehilangan tandan buah segar)}

Rumus yang digunakan adalah :

$\bar{x}=\frac{\sum_{i=1}^{n} x_{i}}{n}$

Dimana :

$x=$ Rata-rata dari kejadian risiko pasca panen (loss post-harvest)

$\mathrm{xi}=$ Nilai per periode kajadian berisiko (selama 12 bulan)

$\mathrm{n}=$ Jumlah data (12 bulan)

\section{Menghitung nilai standar deviasi dari kejadian berisiko}

Menggunakan rumus:

$$
s=\sqrt{\frac{\sum_{i-1}^{n}\left(x_{i}-\bar{x}\right)^{2}}{n-1}}
$$

Dimana:

$\mathrm{S}=$ Standar Deviasi dari kejadian berisiko $\mathrm{xi}=$ Nilai per periode kejadian berisiko $\mathrm{n}=$ Jumlah data (12 bulan)

\section{Menghitung z-score}

Menggunakan rumus:

$$
s=\frac{x-\bar{x}}{s}
$$

Dimana:

$\mathrm{z}=$ Nilai z-score dari kejadian risiko

$\mathrm{x}=$ Batas minimum produksi TBS yang dianggap masih taraf normal

$\mathrm{s}=$ Standar deviasi

jika hasil z-score yang diperoleh bernilai negatif, maka nilai tersebut berada di sebelah kiri nilai rata-rata pada kurva distribusi normal dan sebaliknya jika nilai $\mathrm{z}=$ score positif, maka nilai tersebut berada di sebelah kanan kurva distribusi z (normal).

\section{Mencari probabilitas terjadinya risiko produksi}

Probabilitas diperoleh dari tabel distribusi z. Cari nilai z pada sisi kiri dan bagian atas, pertemuan antara nilai $\mathrm{z}$ pada isi tabel merupakan probabilitas.Sehinga dapat diketahui berapa persen kemungkinan terjadinya keadaan dimana produksi TBS mendatangkan kerugian.

\section{Analisis Dampak Risiko}

Metode yang paling efektif digunakan dalam mengukur dampak risiko adalah VaR (Value at Risk).VaR adalah kerugian terbesar yang mungkin terjadi dalam rentang waktu tertentu yang diprediksikan dengan tingkat kepercayaan tertentu.Penggunaan $\mathrm{VaR}$ dalam mengukur dampak risiko hanya dapat dilakukan apabila terdapat data historis sebelumnya. Analisis ini dilakukan untuk mengukur dampak dari risiko pasca panen berupa kehilangan hasil dari tandan buah segar (TBS) kelapa sawit. adapun rumus yang digunakan adalah sebagai berikut:

$$
V a R=\bar{x}+z\left(\frac{S}{\sqrt{n}}\right)
$$

Dimana:

$\mathrm{VaR}=$ Dampak kerugian yang ditimbulkan oleh kejadian berisiko $x=$ Nilai rata-rata kerugian (kehilangan hasil)

$\mathrm{z}=$ Nilai z-score

$\mathrm{s}=$ Standar deviasi kerugian akibat kejadian berisiko

$\mathrm{n}$ = Banyaknya kejadian berisiko

\section{Pengukuran Kehilangan Hasil TBS}

Pengukuran kehilangan hasil TBS ini dihitung sesuai dengan alur yang dilewati oleh TBS dari petani hingga ke tempat pengolahan akhir (pabrik). 
Pengukuran ini akan menggambarkan seberapa besar kehilangan tandan buah segar (TBS) di setiap alur yang dilewatinya dengan menggunakan rumus berdasarkan referensi jurnal ilmiah Nugraha et al. (2007) yaitu besarnya kehilangan ketika pemanenan adalah sebagai berikut:

$$
\mathrm{KHPP}=\frac{\mathrm{G} 1}{\mathrm{G} 1+\mathrm{G} 2} \times 100 \%
$$

Dimana : KHPP = Kehilangan hasil pada saat panen (\%) G1 = Berat berondolan atau buah yang tercecer pada saat pemanenan G2 = Berat TBS yang dipanen Ketika selesai pemanenan, biasanya TBS akan diangkut menuju ke tempat berikutnya dan akan dikumpulkan di suatu tempat agar bisa diangkut dengan hasil produksi TBS petani lainnya. Maka dengan kata lain, TBS akan menuju ketempat kedua, dimana TBS akan di angkut dan disimpan dan biasanya TBS tersebut dikumpulkan dan dingkut keesokan harinya. Berat TBS ketika diangkut ke tempat lain dan diangkut kembali akan ada perbedaan berat dari total TBS yang dibawa karena terdapat brondolan atau buah kecil yang tidak terangkut. Maka rumus yang digunakan untuk menghitung tingkat kehilangan ketika pengangkutan berdasarkan referensi jurnal ilmiah Enobakhare and LawOgbomo (2002) yaitu:

$$
\mathrm{Wt} . \text { loss }=\frac{(\mathrm{Wi}-\mathrm{Wf})}{\mathrm{Wi}} \times 100 \%
$$

Dimana:

Wt.loss = Jumlah yang hilang $(\%)$

$\mathrm{Wi}=$ Berat awal sebelum di angkut $(\mathrm{kg})$

$\mathrm{Wf}=$ Berat setelah di angkut $(\mathrm{kg})$

Setelah mengetahui berapa jumlah kehilangan tiap jalur yang dilalui, maka dilakukan pemetaan sesuai dengan jalur yang dilalui TBS hingga sampai ke pabrik pengolahan kelapa sawit dengan mencantumkan setiap kerugian yang ada dalam bentuk nominal rupiah sesuai dengan banyaknya berat TBS yang hilang (bentuk brondolan) menggunakan rumus:

$$
\mathrm{TR}=\mathrm{P} \times \mathrm{Q}
$$

Dimana:

$\mathrm{TR}=$ Total Revenue dari brondolan yang hilang (Rp)

$\mathrm{P}=$ harga kelapa sawit per $\mathrm{kg}$

$\mathrm{Q}=$ jumlah brondolan atau TBS yang hilang $(\mathrm{kg})$

\section{HASIL PENELITIAN}

\section{Kemampuan manajemen petani dalam pengelolaan perkebunan kelapa sawit rakyat di Kab. Dharmasraya}

Pengelolaan perkebunan kelapa sawit rakyat mulai dari pemilihan bibit unggul, pemeliharaan, pemupukan, kesesuaian lahan, faktor alam, kapasitas tenaga kerja sebagai pengelola sampai kepada manajemen panen. Hal ini akan menjadi indikator keberhasilan petani dalam pengelolaan perkebunan kelapa sawit. Petani rakyat belum mempunyai pengetahuan yang baik terkait dengan pemilihan bibit. Hanya $20 \%$ petani yang mengetahui asal bibit kelapa sawit yang mereka gunakan. Petani membedakan bibit yang mereka gunakan dengan bibit pelepah panjang dan bibit pelepah pendek.

Pada umumnya petani telah mempunyai pengatahuan yang baik terkait dengan persiapan areal tanam dan penanaman. Jarak tanam yang di aplikasikan petani pada tanaman kelapa sawit umunya adalah $9 \times 9 \mathrm{~m}$ dan $8 \times 9$ m. Petani tidak entensif melakukan pemupukan dengan pertimbangan dana yang akan dikeluarkan. Pemupukan yang sesuai standar harus dilakukan $2 \mathrm{x}$ 
setahun, sekitar $90 \%$ petani hanya melakukan pemupukan satu kali dalam setahun. Pembersihan lahan dilakukan tidak teratur sesuai dengan kebutuhan saja.

Standar buah panen kelapa sawit yang diaplikasikan oleh petani adalah pada saat buah kelapa sawit telah jatuh dari tandannya sebanyak 5 butir atau di sebut brondol 5, ini berdasarkan kearifan lokal atau berdasarkan standar yang dibuat oleh petani dengan toke/tengkulak. $20 \%$ petani melakukan panen hingga 4 kali dalam satu bulan pada musim hujan dan 3 kali dalam satu bulan pada musim kemarau selebihnya melakukan panen 2 kali dalam sebulan atau sekali 15 hari.

Tandan buah segar kelapa sawit harus diolah dalam waktu 24-48 jam sejak dipanen agar tidak mengalami penurunan kualiatas. Jika pengolahan tidak berjalan secara tepat waktu, maka produknya tidak lagi memenuhi persyaratan kelas pangan yaitu kandungan Asam Lemak Bebas (FFA) sekitar 5-6\% (Fricke, 2009). Oleh karena itu diperlukan kecepatan dan ketepatan dalam menyampaikan hasil panen ke pabrik.

\section{Analisis Resiko}

Risiko penanganan pasca panen merupakan risiko yang terjadi di setiap rantai penanganan pasca panen TBS, yaitu dari pemanenan di lahan sampai pabrik pengolahan. Masing-masing tahapan ini akan menimbulkan risiko kehilangan produksi TBS (loss post harvest) dari produksi TBS yang berbentuk brondolan maupun TBS yang terpanen. Banyaknya loss post-harvest yang terjadi akan mempengaruhi pendapatan petani, dimana terjadi penurunan jumlah produksi TBS yang bernilai ekonomis.
Pemanenan kelapa sawit berupa TBS, yang dilakukan oleh petani sendiri atau menggunakan Tenaga Kerja Luar Keluarga (TKLK). selanjutnya pengangkutan TBS yang telah jatuh di area lingkaran pohon dan sekitar melalui tempat pengumbulan hasil (TPH). Dalam tahapan ini biasanya akan terlihat TBS mentah yang terpanen oleh pemanen kelapa sawit. Setelah terkumpul di TPH maka TBS akan dimuat ke dalam truck, kemudian dilanjutkan untuk dibawa ke pabrik.

\section{Dipabrik pengolahan kelapa} sawit TBS yang akan dijual petani kepabrik akan dilakukan penyortiran buah terlebih dahulu, penyortiran dilakukan untuk memisahkan buah yang mentah busuk dan matang. Untuk buah yang matang akan dibeli dan untuk yang mentah serta busuk tidak diterima atau dipulangkan kepada petani atau pilihan lainnya ditinggalkan dipabrik. Buah yang mentah mengandung rendemen yang sedikit, sedangkan yang busuk mengandung minyak yang tidak berkualitas atau kandungan air dan FFA nya tinggi, serta tangkai TBS yang terlalu panjang juga akan menguragi rendemen buah kelapa sawit pada saat proses perebusan, sehingga perlu dilakukan penyortiran buah oleh pihak pabrik agar rendemen yang tinggi dengan kualitas minyak yang bagus tercapai.

Setelah buah petani disortir apabila tidak ditemukan buah busuk dan mentah namun ditemukan tangkai TBS yang panjang yang berukuran lebih dari $2 \mathrm{~cm}$ maka akan dilakukan pemotongan pada kilogram TBS yang dijual biasanya akan dipotong sebesar 4,5 sampai 5\% di PT. Bina Pratama Sakato Jaya Kiliran Jao. $4,5 \%$ berarti misalkan dalam 1 ton atau $1000 \mathrm{~kg}$ akan dipotong sebesar 45 $\mathrm{kg}$ sehingga berat bersih yang diterima petani sebesar $955 \mathrm{~kg}$ yang kemudian 
baru di kalikan dengan harga pabrik atau pemegang D.O. Namun apabila ditemukan buah mentah dan busuk tentu potongan sortasinya akan lebih banyak lagi.
Berdasarkan pemaparan diatas, maka dapat disimpulkan pada tabel 1 sebaran persentase kehilangan hasil pasca panen TBS di Dhamasraya pada setiap rantai yang dilaluinya.

Tabel 1. Sebaran persentase kehilangan hasil pasca panen kelapa sawit di Dhamasraya

\begin{tabular}{llr}
\hline No & Tempat Kehilangan (post losses) & \% kehilangan hasil produksi (losses) \\
\hline 1 & losses di lahan & 3,85 \\
\hline 2 & losses pengecekan TBS mentah & 0,05 \\
\hline 3 & Losses di sortasi pabrik & 5,5 \\
\hline & Total & 9,4 \\
\hline
\end{tabular}

Berdasarkan besar kehilangan hasil produksi kelapa sawit di Dhamasraya, loss post harvest bernilai $9,4 \%$ dari total produksi yang dihasilkan oleh petani kelapa sawit yaitu sebesar 7943,83 Kilogram perbulannya.
Analisis kemungkinan terjadinya (Probabilitas) Lost Post Harvest TBS

Probabilitas kehilangan hasil produksi di lahan

Analisis pada rantai poss harvest TBS di lahan dilakukan untuk mengetahui probabilitas tingkar risiko yang dihadapi petani kelapa sawit di Dhamasraya yaitu brondolan yang berserakan di pinggiran tanaman kelapa sawit. Berikut ini adalah probabilitas kehilangan hasil produksi lahan yang akan dijelaskan pada tabel. 
Tabel 2. Analisis perhitungan probabilitas Kehilangan hasil produksi di lahan

\begin{tabular}{lcrr}
\hline \multicolumn{1}{c}{ Bulan } & $\begin{array}{c}\text { Produksi awal } \\
(\mathbf{k g}) \mathbf{X} / \mathbf{h a})\end{array}$ & $\begin{array}{c}\text { Jumlah losses } \\
(\mathbf{k g}) \mathbf{X i} / \mathbf{h a})\end{array}$ & \multicolumn{1}{c}{$\begin{array}{c}\text { Produksi akhir } \\
(\mathbf{k g})(\mathbf{X}-\mathbf{X i}) / \mathbf{h a}\end{array}$} \\
\hline Januari & $6.377,15$ & 4,46 & $6.372,69$ \\
\hline Februari & $7.373,67$ & 4,28 & $7.369,39$ \\
\hline Maret & $6.967,67$ & 4,22 & $6.963,45$ \\
\hline April & $6.968,27$ & 4,16 & $6.964,11$ \\
\hline Mei & $6.665,45$ & 3,98 & $6.661,47$ \\
\hline Juni & $7.866,71$ & 3,92 & $7.862,79$ \\
\hline Juli & $9.364,37$ & 3,56 & $9.360,81$ \\
\hline Agustus & $7.666,41$ & 3,62 & $7.662,79$ \\
\hline September & $10.566,77$ & 3,98 & $10.562,79$ \\
\hline Oktober & $7.264,85$ & 3,38 & $7.261,47$ \\
\hline November & $9.864,61$ & 3,8 & $9.860,81$ \\
\hline Desember & $9.864,62$ & 3,81 & $9.860,81$ \\
\hline Januari & $8.465,68$ & 4,21 & $8.461,47$ \\
\hline Februari & $6.464,86$ & 4,05 & $6.460,81$ \\
\hline Maret & $6.764,67$ & 3,86 & $6.760,81$ \\
\hline April & $8.064,13$ & 2,66 & $8.061,47$ \\
\hline Mei & $7.863,35$ & 2,54 & $7.860,81$ \\
\hline Juni & $8.065,45$ & 2,66 & $8.062,79$ \\
\hline Juli & $9.568,03$ & 3,26 & $9.564,77$ \\
\hline Agustus & $6.964,37$ & 2,9 & $6.961,47$ \\
\hline Total & & & $158.957,85$ \\
\hline Rata-rata & & & $7.947,89$ \\
\hline Standar deviasi & & & 2342,93 \\
\hline X & & & 60,831390555 \\
\hline Z & & & 0,2033 \\
\hline Nilai pada tabel Z & & & $\mathbf{2 0 , 3}$ \\
\hline Probabilitas & & & \\
\hline & & & \\
\hline
\end{tabular}

Berdasarkan analisis yang dilakukan pada Tabel 2, kemungkinan terjadimya loss (kehilangan) hasil produksi dibagian lahan adalah sebesar 20,3 persen. Hasil perhitungan tersebut didapat dari perhitungan nilai standar dengan hasil nilai z-score nya sebesar 0,83 , tanda minus pada nilai $\mathrm{z}$-score menjelaskan bahwa nilai kejadian loss di lahan berada disebelah kiri nilai rata-rata pada kurva sebaran normal. Setelah diketahui nilai z-score nya, maka selanjutnya adalah melihat nilai yang tertera di tabel sebaran normal (nilai tabel Z) yaitu sebesar 0,2033. Maka kemungkinan kejadian kehilangan hasil produksi (loss postharvest) di bagian lahan adalh $20,3 \%$.

\section{Probabilitas kehilangan hasil produksi di TPH (pengecekan TBS Mentah)}

Probabilitas kehilangan hasil produksi ditempat pengumpulan hasil (TPH) guna untuk melihat kemungkinan dan mengetahui tingkat risiko yang dihadapi oleh petani kelapa sawit di Dhamasraya pada brondolan yang tidak terangkut di TPH. Berikut akan dijelaskan pada Tabel 3. 
Tabel 3. Analisis perhitungan probabilitas TBS mentah

\begin{tabular}{lrrr}
\hline \multicolumn{1}{c}{ Bulan } & $\begin{array}{c}\text { Produksi Awal } \\
(\mathbf{k g}) \mathbf{X} / \mathbf{h a}\end{array}$ & $\begin{array}{c}\text { Jumlah Losses } \\
(\mathbf{k g} / \mathbf{h a})\end{array}$ & Produksi Akhir $\mathbf{( k g )} \mathbf{X}-\mathbf{X i )} \mathbf{h a}$ \\
\hline Januari & $6.372,69$ & 13,86 & $6.358,83$ \\
\hline Februari & $7.369,39$ & 10,56 & $7.358,83$ \\
\hline Maret & $6.963,45$ & 4,62 & $6.958,83$ \\
\hline April & $6.964,11$ & 5,28 & $6.958,83$ \\
\hline Mei & $6.661,47$ & 2,64 & $6.658,83$ \\
\hline Juni & $7.862,72$ & 3,96 & $7.858,83$ \\
\hline Juli & $9.360,81$ & 1,98 & $9.358,83$ \\
\hline Agustus & $7.662,79$ & 3,96 & $7.658,83$ \\
\hline September & $10.562,79$ & 3,96 & $10.558,83$ \\
\hline Oktober & $7.261,47$ & 2,64 & $7.258,83$ \\
\hline November & $9.860,81$ & 1,98 & $9.858,83$ \\
\hline Desember & $9.860,81$ & 1,98 & $9.858,83$ \\
\hline Januari & $8.461,47$ & 2,64 & $8.458,83$ \\
\hline Februari & $6.460,81$ & 1,98 & $6.458,83$ \\
\hline Maret & $6.760,81$ & 1,98 & $6.758,83$ \\
\hline April & $8.061,47$ & 2,64 & $8.058,83$ \\
\hline Mei & $7.860,81$ & 1,98 & $7.858,83$ \\
\hline Juni & $8.062,79$ & 3,96 & $8.058,83$ \\
\hline Juli & $9.564,77$ & 5,94 & $9.558,83$ \\
\hline Agustus & $6.961,47$ & 2,64 & $6.958,83$ \\
\hline Total & & & $158.876,67$ \\
\hline Rata-rata & & & $7.943,83$ \\
\hline Standar Deviasi & & & $2.344,63$ \\
\hline X & & & 6.000 \\
\hline Z & & & $-0,82905803$ \\
\hline Nilai pada tabel Z & & & 0,2061 \\
\hline Probabilitas & & & \\
\hline & & & \\
\hline
\end{tabular}

Berdasarkan analisis yang dilakukan pada Tabel 3, kemungkinan terjadimya loss akibat TBS mentah yang terpanen adalah 20,61\%. Hasil perhitungan tersebut didapat dari perhitungan nilai standar dengan hasil nilai $\mathrm{z}$-score nya sebesar $-0,82$, tanda minus pada nilai z-score menjelaskan bahwa nilai kejadian loss pengecekan TBS mentah berada disebelah kiri nilai rata-rata pada kurva sebaran normal. Setelah diketahui nilai z-score nya, maka selanjutnya adalah melihat nilai yang tertera di tabel sebaran normal (nilai tabel Z) yaitu sebesar 0,2061. Maka kemungkinan kejadian kehilangan hasil produksi pada proses pemeriksaan TBS mentah yang terpanen adalah $20,61 \%$. 
Probabilitas kehilangan hasil memenuhi kriteria pabrik untuk produksi di pabrik (sortasi)

kemudian kembalikan kepada petani yang ditolak tersebut. Perhitungan probabiliti kehilangan hasil TBS yang bersumber dari sortasi yang dilakukan di pabrik disaajikan pada Tabel 4.

Tabel 4. Analisis perhitungan probabilitas kehilangan produksi di pabrik (sortasi)

\begin{tabular}{|c|c|c|c|c|}
\hline Bulan & $\begin{array}{l}\text { Produksi Awal } \\
\text { (kg) X /ha }\end{array}$ & $\begin{array}{c}\text { Potongan } \\
\text { Pabrik (\%) }\end{array}$ & $\begin{array}{l}\text { Jumlah } \\
\text { Losses } \\
\text { (kg/ha) } \\
\end{array}$ & $\begin{array}{l}\text { Produksi Akhir } \\
\text { (kg) X-Xi)/ha }\end{array}$ \\
\hline Januari & $6.358,83$ & 5,56 & 353,30 & $6.005,53$ \\
\hline Februari & $7.358,83$ & 5,55 & 408,13 & $6.950,70$ \\
\hline Maret & $6.958,83$ & 5,55 & 386,20 & $6.572,63$ \\
\hline April & $6.958,83$ & 5,55 & 386,20 & $6.572,63$ \\
\hline Mei & $6.658,83$ & 5,55 & 369,77 & $6.289,07$ \\
\hline Juni & $7.858,83$ & 5,54 & 435,57 & $7.423,27$ \\
\hline Juli & $9.358,83$ & 5,53 & 517,80 & $8.841,03$ \\
\hline Agustus & $7.658,83$ & 5,54 & 424,60 & $7.234,23$ \\
\hline September & $10.558,83$ & 5,53 & 583,60 & $9.975,23$ \\
\hline Oktober & $7.258,83$ & 5,53 & 402,67 & $6.856,17$ \\
\hline November & $9.858,83$ & 5,53 & 545,23 & $9.313,60$ \\
\hline Desember & $9.858,83$ & 5,53 & 545,23 & $9.313,60$ \\
\hline Januari & $8.458,83$ & 5,54 & 468,47 & $7.990,37$ \\
\hline Februari & $6.458,83$ & 5,56 & 358,80 & $6.100,03$ \\
\hline Maret & $6.758,83$ & 5,55 & 375,23 & $6.383,60$ \\
\hline April & $8.058,83$ & 5,54 & 446,53 & $7.612,30$ \\
\hline Mei & $7.858,83$ & 5,54 & 435,57 & $7.423,27$ \\
\hline Juni & $8.058,83$ & 5,54 & 446,53 & $7.612,30$ \\
\hline Juli & $9.558,83$ & 5,53 & 528,77 & $9.030,07$ \\
\hline Agustus & $6.958,83$ & 5,55 & 386,20 & $6.572,63$ \\
\hline Total & & & & $15.0072,27$ \\
\hline Rata-rata & & & & $7.503,61$ \\
\hline \multicolumn{2}{|c|}{ Standar Deviasi } & & & $1.342,21$ \\
\hline \multicolumn{2}{|l|}{$\mathrm{X}$} & & & 6.000 \\
\hline \multicolumn{2}{|l|}{$\bar{Z}$} & & & $-1,120252769$ \\
\hline \multicolumn{2}{|c|}{ Nilai pada tabel Z } & & & 0,1314 \\
\hline \multicolumn{2}{|c|}{ Probabilitas } & & & 13,1 \\
\hline
\end{tabular}

Berdasarkan analisis yang dilakukan pada Tabel 4, probabilitas kejadian hilangnya hasil produksi di bagian sortasi pabrik adalah sebesar 13,1 persen. Hasil ini diperoleh dari perhitungan nilai standar yang 
menghasilkan nilai z-score sebesar 1,12 . Tanda minus yang tertera pada nilai $\mathrm{z}$-score menandakan bahwa nilai z-score kehilangan hasil produksi di bagian sortasi pabrik berada di sebelah kiri ratarata nilai pada kurva sebaran normal. Setelah diketahui nilai z-score, maka selanjutnya adalah melihat nilai yang terdapat pada tabel sebaran normal (tabel Z) yaitu sebesar 0,1314, Maka kemungkinan terjadinyakejadian loss post-harvest yang terdapat di bagian sortasi pabrik adalah sebesar $13,1 \%$.
3. Analisis dampak kehilangan hasil produksi (Lost postharvest) TBS

Analisis dampak risiko dilakukan untuk mengetahui seberapa besar dampak yang ditimbulkan akibat kehilangan hasil produksi di setiap tahapan pasca panen. Besarnya kerugian diketahui dari perkalian antara jumlah loss TBS disetiap tahapan pasca dengan harga TBS per kilogram yaitu sebesar Rp 1.810,00. Berikut akan dijelaskan analisis dampak kehilangan hasil pada Tabel 5.

Tabel 5. Analisis dampak kehilangan hasil produksi TBS

\begin{tabular}{lrrr}
\hline Bulan & Lahan/ha & TBS mentah/ha & Sortasi pabrik/ha \\
\hline Januari & 8072,6 & 25086,6 & 639473,0 \\
\hline Februari & 7746,8 & 19113,6 & 738721,3 \\
\hline Maret & 7638,2 & 8362,2 & 699022,0 \\
\hline April & 7529,6 & 9556,8 & 9688444,9 \\
\hline Mei & 7203,8 & 4778,4 & 7067572,2 \\
\hline Juni & 7095,2 & 7167,6 & 3642295,6 \\
\hline Juli & 6443,6 & 3583,8 & 4948511,0 \\
\hline Agustus & 6552,2 & 7167,6 & 2028908,6 \\
\hline September & 7203,8 & 7167,6 & 4183011,4 \\
\hline Oktober & 6117,8 & 4778,4 & 1443076,8 \\
\hline November & 6878 & 3583,8 & 3908014,4 \\
\hline Desember & 6896,1 & 3583,8 & 3908014,4 \\
\hline Januari & 7620,1 & 4778,4 & 2238521,1 \\
\hline Februari & 7330,5 & 3583,8 & 1285867,4 \\
\hline Maret & 6986,6 & 3583,8 & 1344761,2 \\
\hline April & 4814,6 & 4778,4 & 2133714,9 \\
\hline Mei & 4597,4 & 3583,8 & 1560983,8 \\
\hline Juni & 4814,6 & 7167,6 & 1600286,2 \\
\hline Juli & 5900,6 & 10751,4 & 2526658,6 \\
\hline Agustus & 5249 & 4778,4 & 1384063,6 \\
\hline Total & $\mathbf{1 3 2 6 9 1 , 1}$ & $\mathbf{1 4 6 9 3 5 , 8}$ & $\mathbf{5 6 9 6 9 9 2 2 , 6}$ \\
\hline Rata-rata & 6634,56 & 7346,79 & 2848496,128 \\
\hline Standar deviasi & 1969,910 & 7701,087 & 87,75583743 \\
\hline Z(5\%) & 1,645 & $\mathbf{1 0 1 7 9 , 5 1}$ & 1,645 \\
\hline Var (Rp) & $\mathbf{7 3 5 9 , 1 5}$ & & $\mathbf{2 8 4 8 5 2 8 , 4 1}$ \\
\hline & & & \\
\hline & & & \\
\hline
\end{tabular}


Berdasarkan analisis yang dilakukan pada penggunaan selang kepercayaan $95 \%$ menunjukkan kerugian Value at Risk (VaR) pada kejadian risiko di bagian lahan sebesar Rp 7.359,15, TBS mentah terpanen adalah sebesar Rp 10.179,51, dan di sortasi pabrik sebesar Rp 2.848.528,41. Nilai kerugian yang diterima petani di setiap tahapan pasca panen tersebut menunjukkan nilai kerugian maksimum, namun ada $5 \%$ kemungkinan kerugian yang diterima lebih besar dari Rp 2.848.528,41. Kerugian terbesar terletak pada sortasi pabrik, artinya banyak TBS yang dihasilkan petani tidak memenuhi standar pabrik.

Adapun permasalahan petani kelapa sawit dari di Trimulya dan Kampung Surau Dhamasrayaadalah petani tidak mengindahkan bagaimana pentingnya rendemen kelapa sawit. Petani hanya mementingkan berat TBS nya saja, kadang dipupuk pada saat tidak ada biaya tidak dipupuk, pemanenan dengan tangkai panjang, buah tidak diangkut secepatnya, dari segi pabrik, tujuan utama pabrik saat pemrosesan adalah mengurangi kehilangan minyak atau meminimalisir oil losses, kurangnya komunikasi pabrik dengan petani sehingga tidak terjalinnya kerja sama berdasarkan sistem agribisnis.

\section{KESIMPULAN}

Manajemen yang dilakukan oleh petani TBS di Dhamasraya belum efektif, dimana masih terdapat kekurangan pada Pengelolaan perkebunan kelapa sawit rakyat mulai dari pemilihan bibit unggul, pemeliharaan, pemupukan, kesesuaian lahan, faktor alam, kapasitas tenaga kerja sebagai pengelola sampai kepada manajemen panen. Hal ini akan menjadi indikator keberhasilan petani dalam pengelolaan perkebunan kelapa sawit.
Petani rakyat belum mempunyai pengetahuan yang baik terkait dengan pemilihan bibit. Hanya $20 \%$ petani yang mengetahui asal bibit kelapa sawit yang mereka gunakan.

Persentasi loss post-harvest tandan buah segar (TBS) adalah sebesar 9,4\% dari seluruh total rata-rata TBS yang dihasilkan pada setiap rantainya. Dampak kerugian yang ditimbulkan dari loss post-harvest TBS secara total per hektar lahan sebasar Rp 2.848.528,41 pada sortasi pabrik, dan merupakan kerugian terbesar dibandingkan dengan rantai lainnya.

Peningkatan sumber daya manusia (SDM) pemanen dengan cara Penyuluhan tentang standar kematangan buah berdasarkan fraksi sangat perlu dilakukan karena proses pemanenan sangat menentukan risiko kehilangan produksi sampai pada tahapan-tahapan yang dilaui TBS selanjutnya.

Melakukan kerja sama dengan Pabrik dengan cara pengawasan langsung dari perusahaan secara kualitas dan kriteria matang panen yang sesuai dengan standar pabrik sehingga potongan yang diterima oleh menjadi lebih kecil.

\section{DAFTAR PUSTAKA}

Afifuddin, S., Kusuma, SI. 2007. Analisis Struktur Pasar CPO: Pengaruhnya terhadap pengembangan ekonomi wilayah Sumater Utara. Jurnal Perencanaan dan Pengembangan Wilayah. Vol. 2 No. 3. April 2007. Hal $124-136$.

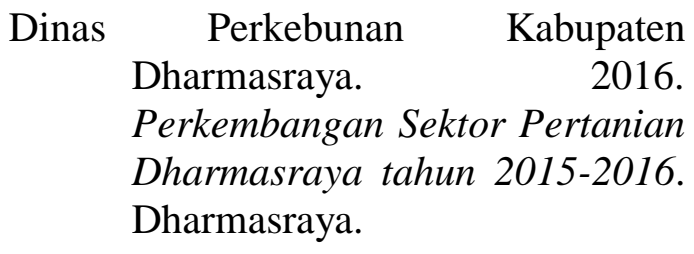


Dirjen Perkebunan. 2014. Statistik Perkebunan Komoditas Kelapa Sawit 2013-2015. Jakarta. Dirjen Perkebunan.

Fricke, Thomas B. 2009. Buku Panduan Pabrik Kelapa Sawit Skala Kecil untuk Produksi Bahan Baku Bahan Bakar Nabati (BBN). Environmental ServicesProgram (ESP). Aceh. Indonesia. Hal 2.

K.E. Law-Ogbomo, 2007. Reduction of Post-Harvest Loss Caused by
Callosobruchus maculatus (F.) in Three Varieties of Cowpea Treated with Plant Oils. Journal of Entomology, 4: 194-201.

Nugraha, Sigit et al. . 2007. Keragaan Kehilangan Hasil Pasca panen Padi Pada 3 (tiga) Agroekosistem. Jakarta: BBPP.

Pahan, I. 2010. Kelapa Sawit Manajemen Agribisnis dari Hulu Hingga Hilir. Penebar Swadaya, Jakarta. 411 hal. 